\section{Budashko V., Glazeva D., Samonov 5.}

\title{
CONCEPTUALIZATION OF RESEARCH OF POWER HYBRID ELECTRIC POWER COMPLEXES
}

На підставі аналізу способів моделювання різних експлуатаційних режимів суднової енергетичної установки (СЕУ) гібридного дизель-електричного пропульсивного комплексу (ДЕПК) з точки зору споживання енергї̈, отримано динамічні характеристики процесів передачі потужностей на різних ділянках гібридного ДЕПК. Це дозволило конщептуалізувати принщипи налагодження систем управління розподіленням електроенергї для різних експлуатаційних режимів в умовах недетермінованих навантажень.

Ключові слова: гібридний пропульсивний комплекс, альтернативне джерело енергї, сонячний генеруючий елемент, акумуляторна батарея, моделювання.

\section{Introduction}

Stringent requirements of environmental protection, the future transition to a more expensive fuel grades with low sulfur content, reduction of harmful emissions, reduction of the noise characteristics of vessels in certain areas of navigation, allocation of certain areas of shipping and ports, which excludes the work of ship diesel engines cause the need to find alternative energy sources that meet the increased requirements of maritime and environmental legislation [1].

Research of alternative diesel and gas engines for ship power units (SPU) of combined propulsion systems (CPC), which focuses on the system of exhaust heat recovery, led to significant savings in annual operating costs, but did not solve environmental problems.

The use of heat recovery systems, which compensate a part of the electricity consumption, and devices to reduce harmful emissions into the atmosphere is promising direction of SPU CPC building, but today is one that is losing relevance.

This fact forced to critically rethink an experience of use of accumulator, solar and hydrogen energy sources for the purposes of ship electricity, ensure the safety of their operation and improve their production technology and obtain an approval of the leading Classification societies [2]. An important feature of advanced battery systems is their ability to be charged from the heat extraction systems, recovery from the ship cranes during the braking modes, for shaft generators and renewable energy sources such as solar and hydrogen elements. So today, it is necessary takes into account this fact for design and building of modern SPU CPC.

\section{The object of research and its technological audit}

The object of research is a hybrid diesel-electric propulsion complex (DEPC). The variant of its block diagram is shown in Fig. 1. Other decisions related to the integration improvement of providing hybrid DEPCs, SPUs and SPPs are given in [3-9].

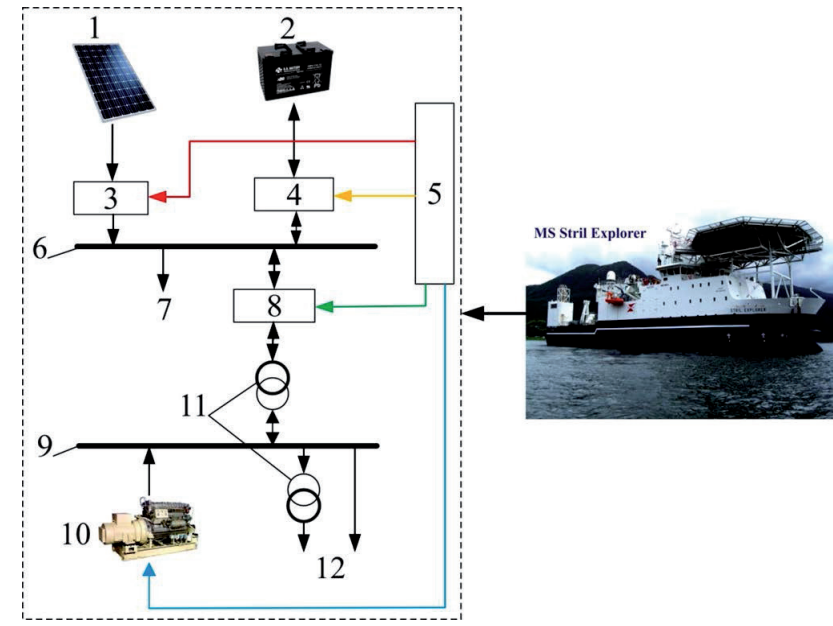

Fig. 1. Block functional diagram of combined (hybrid) propulsion complex: 1 - Photovoltaic generation system (PVGS); 2 - energy storage system (ES5); 3, 4 - DC/DC converter; 5 - control system (CS) of hybrid diesel-electric propulsion complex (DEPC); 6 - DC-link; 7 - to DC consumers - such as resistor back unit (RBU); 8 - voltage source inverter (VSI) or current source inverter (CSI), 9 - high voltage switchboard (HVSB); 10 - ships power plant (SPP) with medium speed engines (MSE); 11 - voltage transformers, 12 - to AC consumers, in particular, board electric motor (BEM), thruster (THR) and low voltage switchboard (LVSB)

Hybrid DEPC is shown in Fig. 1. It is based on the electric power complex of offshore ship, operating in dynamic positioning mode and consists of the following elements:

KC200GT-based PVGS modules with nominal power of $10 \mathrm{~kW}$ (maximum 11,5 kW) and output voltage of $30-60 \mathrm{~V}$.

Lithium-ion batteries (LIB)-based ESS with system voltage of $48 \mathrm{~V}$ and a capacity of $4,000 \mathrm{~A} \cdot \mathrm{h}$.

Power DC/DC converters of PSC18 type with nominal power of $40 \mathrm{~kW}$, nominal current and voltage on the DC-link of $200 \mathrm{~A}$ and $450 \mathrm{~B}$, respectively, are designed to enhance and regulate the voltage in the PVGS output and limits the input current and to discharge and recharge of ESS batteries. These converters are bidirectional and allow to regulate the output voltage of the current limit 
and are used to redistribute of the power between the components of hybrid DEPC.

VSI power modules of PWS-F (PWS-W) type with the maximum total capacity of $300 \mathrm{~kW}$, a voltage of $450 \mathrm{VDC}, 440 \mathrm{VAC}$ and $50 \mathrm{~Hz}$, which allow to adjust the power factor depending on MSE load.

RBU with capacity of $5 \mathrm{~kW}$ intended to avoid overload of PVGS and ESS.

Power three-phase transformers with respective power are used for coordination between HVSB and LVSB of hybrid DEPC.

CS of hybrid DEPC distributes the power between PVGS, ESS and SPP according to the chosen strategy of power consumption:

- State Machine Control Strategy (SMCS).

- Classical PI Control Strategy with SOC's Regulation.

- Frequency decoupling and state machine control

strategy with SOC's regulation).

- Equivalent consumption minimization strategy.

- External energy maximization strategy with SOC's regulation.

The main purpose of PVGS as alternative energy source (AES) in the given hybrid DEPC is SPP activation after power failure and power support of the ship operation in the maneuvering modes, one of which is the mode of dynamic positioning (DP). Depending on the chosen strategy of power consumption, CS regulates the power of each energy source according to the specified output voltage and maximum current of PVGS, ESS and converters (DC/DC converters, VSI).

The disadvantages of given block diagram of hybrid DEPC are:

- Inconsistency of MSE parameters with other components, leading to uneven magnetic flux regulation and voltage amplitudes, which causes further increase additional ripple voltage in the outputs of converters and an emergence of equalization currents during synchronous operation.

- High level of harmonics in the current of energy consumers.

- Reduced reliability, efficiency, increased size and weight that occur through the use of high power elements and sets of equipment for them.

- Inability to balancing of three-phase power supply system with uneven loading phases.

\section{The aim and objectives of research}

The aim of research - to improve the control system of power processes in ships hybrid DEPCs performed with the use of AESs.

To achieve this aim it is necessary to perform the following tasks:

1. Prove the possible ways of improving the structural and block diagrams of hybrid DEPCs developed using AESs taking into account modern results in their development.

2. Identify the most important factors of operating modes for hybrid DEPCs with AESs affecting the quality of consumed electricity in terms of non-determined load.

3. Make comparative mathematical modeling of energy processes in hybrid DEPCs with AESs in different operating modes for their parameterization and determination of boundary conditions for trouble-free operation.

\section{Literature review}

Renewable energy sources, especially solar, wind power are more penetrating in the shipbuilding sector. However, long-term storage of energy is a universal problem in securing support for renewable sources on the basis of electricity with the high availability depending on the season. One way of overcoming this problem is to use hydrogen as an energy vector by which solar and wind energy is transformed, stored and restored at the right time. Hydrogen that derived from water using electrolysis is stored as a compressed gas or metal hydride, and then used from the repository to generate electricity in a fuel cell.

In [10] the authors identified the benefits and problems of various types of fuel cells. Possible opportunities for emission limitation of different types of fuel cells, real devices for merchant ships and warships and projects of the potential innovation and research needs for area of fuel cells are considered.

Detailed analysis of the effectiveness of the ship DC hybrid power system was made in [11]. Also, the authors have developed algorithms for optimizing control systems by the criterion of minimum fuel consumption under different load conditions and achieved $15 \%$ fuel savings of optimally adjusted energy storage in the investigated DC system.

Serious environmental pollution and low efficiency of traditional SPUs, which power is predetermined only by the number of diesel generators, can be reduced by proper integration of renewable energy sources. In recent years, photovoltaic elements have been used in SPU in order to reduce greenhouse gas emissions, increase energy efficiency and strengthen SPP stability. However, the use of too many solar panels can increase the cost of capital investment and make the power system is unstable due to the uncertainty associated with solar energy [12, 13]. In addition, a wide range of studies [14-19] found that the use of energy storage systems (ESS) is one of the most effective solutions for quality, reliability and power of SPP and contributes to greater development of efficient energy distribution. Some studies [20,21] showed that the optimal control of ESS in SPP with multiple bus structures that are built using Flexible Alternative Current Transmission Systems (FACTS) and are the Western System Coordinating Council (WSCC) with the uneven impedance distribution will reduce the peak load, the cost of power supply renovation and compensate the negative impact on the environment.

Hybrid SPP concepts were investigated in the works [22, 23]. Lithium-ion batteries in the integration of diesel SPU for CPC modes with loading and unloading operations was investigated in [22]. To maximize a fuel economy, ESSs were used in the rebuilding of bulker for electric propulsion in [24]. In other works, various strategies that solve problems to maximize battery life and reduce fuel consumption were developed [25, 26].

Many studies of hybrid power systems were published in [27-34]. In particular, the economic and environmental benefits of hybrid DEPC using SPU and storage of energy in ESS were analyzed in [28-30]. The optimal distribution scheme for independent DEPC with integrated wind turbine (WT) and SPU in conditions of their uncertainty in terms of minimizing energy costs and maximum reliability was proposed in [31, 32]. Best practices for improving DEPC and SPU CPC were also proposed in [33, 34]. 
It should be noted that hybrid CPCs in the modern periodic sources not take a first place [35-37]. In [37], SPUs is used in SPPs for reducing fuel costs. Evaluation of stability and economic analysis of hybrid DEPCs was considered in [35]. The authors of [36] proposed a preliminary analysis of measures to reduce harmful emissions into the environment in the port area. In addition, an integration of significant PVGS and ESS power in SPP in reducing $\mathrm{CO}_{2}$ emissions is a challenge. Electricity production by PVGS in SPP depends on its position in the ocean. Previous studies [38-42] of PVGS use take into account the calendar conditions, local time, time zone, operating coordinates in terms of power providing for moving ship. In [40] proposed the optimal choice of hybrid DEPC sizes taking into account different slope angles of PVGS panels. Corrections to the output settings of PVGS panels depending on their location on the ship were obtained because of the strong dependence of parameters and quality of PVGS from climatic conditions such as time of year, local time, operating coordinates. The authors [38] proposed an optimal fundamental structure of hybrid DEPC with wind turbines and various environmental conditions with the methods of gradual PVGS adaptation to the operating conditions. Detailed models of hybrid DEPC with PVGS were created and optimized in [39, 31] that taking into account the actual environmental conditions and uncertain operating situation. An evaluation method of global illumination depending on the PVGS slope was developed in [42], which took into account the temperature and distribution of the solar spectrum.

Analysis of Fig. 1 allow to conclude that the control of hybrid DEPC is a very complex process that requires taking into account a large number of factors of energy and operating components. For example, such component of hybrid DEPC as PVGS is based on the use of lithiumion batteries (LIB) [43].

The variety of SPU CPC modes, when using LIB, determines not only more range of developed capacities and sizes of the batteries, but also a wide voltage range (from seven to several hundred volts) of the batteries based on them that are necessary for the implementation of certain powerful, energy and performance of PVGS [44, 45].

PVGS configuration is complicated in the presence of dangerous external influences, as well as in the case of powerful batteries (especially for hybrid DEPC) that demand an additional air or liquid cooling [46].

Fig. 2 shows a functional block diagram of hybrid DEPC with PVGS fragmentation. General requirements for all LIBs in the design of hybrid DEPCs are safety and ease of use, and full discharge of SB under cyclic mode, but do not work on schedule of weakest element. This is achieved by the introduction of the selective BMS of BMA in PVGS, which monitors the battery charge and protection from dangerous operating modes and provides information on its main parameters [47-49].
Given the high capacity and a large supply of energy and fire-danger of electrolyte in LIB, the main task of BMS of BMA is SB protection in the case of dangerous modes. These primarily include current overload and short circuit of the power circuits, SB overheating, excessive discharge and recharge of LIB. Protection of dangerous operation modes is done by leveling of LIBs voltage unbalance and formation of control signals (CSg) to change the mode of external devices or to SB disable from external power circuits using switching equipment that is structurally located as a part of SBs and beyond them [50, 51].

Given the above, we can conclude that DEPC development requires an additional research in improving energy processes involving the use of alternative energy sources in DEPC. The latter require the development of modern local CS from the point of view of their integration into CS of hybrid DEPC.

\section{Materials and methods of research}

5.1. Improvement of the power processes control system in diesel-electric hybrid propulsion complexes of the ships made using alternative energy sources. Local CS performs voltage measurement of each element in LIB to protect of PVGS against overcharging and overdischarging. Measuring chains of all batteries in this case should be galvanically untied and are designed to operation at a voltage corresponding to the maximum PVGS voltage (Fig. 2). Precision of LIB voltage measurement for most applications should be no worse than $\pm 20 \mathrm{mV}$. With the CSg formation in terms of voltage LIB it is necessary to consider the voltage drop on their internal resistance and temperature.

LIB-element temperature control is necessary to protect ESS from overheating. Recently, for these purposes, temperature sensors with digital or analog output were commonly used. It is relatively easy to use, ensuring measurement 
accuracy $\pm(1-2)^{\circ} \mathrm{C}$. Thermistors or thermocouple are used today for a number of special applications related to ESS operation in extreme conditions or restrictions of use of imported components.

To measure a current in ESS, along with the shunt, Halleffect current sensors are used. Their wide range allows to measure currents ranging from 10 to $1000 \mathrm{~A}$ with an accuracy $\pm 2 \%$. Except calculation of charging and discharging LIB capacities, current level is required to calculate the corrections to the measured LIB voltage values. Current sensors can also be used for protection against current overload of ESS power circuits near fusible inserts or fuses that self-renewing and protect LIB only from short circuit currents and not effective at relatively low (1,5-2-time) current overload.

The most complex challenge in terms of implementation is to ensure ESS efficiency during failures (short circuit or open circuit) inside LIB. Open circuit in LIBs is most dangerous when they are in series connection in SEE, short circuit - for their parallel connection.

In a parallel LIB connection for additional protection from the effects of the internal short circuits, fusible insert is installed in series with each of them.

To maintain SEE efficiency during a failure of one of the LIBs in their series connection it is necessary to exclude it from the power circuit, while maintaining its integrity. It uses electromechanical or electronic bypass device are used for this purpose. They are controlled by local CS and installed directly on LIB to remove of generated heat through them [47].

An important function of the local CS is a hardware leveling of charge (leveling voltage unbalance) for single LIB in ESS. The cause of voltage unbalance is the difference in SB charge rate due to differences in the rate of self-discharge that is defined as leakage currents through internal and external electrical circuits of SB and electrochemical processes occurring on their electrodes. The result of the voltage unbalance is SEE operation on the «worst» (the most discharged inside) LIB, even if it has the largest nominal capacity at all SBs in SEE.

Hardware methods for leveling voltage unbalance can be divided into the following:

1. Passive method that is the most simple to implement, when LIB of high voltage is discharged via the resistor connected in parallel to it.

2. Active methods that ensure SB voltage grading through redistribution of energy between them.

3. Systemic approaches that ensure the individual (independent) charging mode for each LIB.

The most simple, but very effective system method of leveling unbalance in LIBs of large and extra-large capacity is their charging by multi-channel chargers (AC/DC converter) (Fig. 2). For low-voltage portable LIBs are well established circuit solutions that provide an automatic LIBs swapping from the series circuit to parallel circuit in the case of connection of specialized charger to it [52].

Active methods implement transformer circuit of energy redistribution in LIBs and milking of «lagging» SBs is used from one or more DC sources, power supply of which is carried out form SB output or from an external power source (e. g. charger, ESS, another source of renewable energy). These devices provide great flowing currents and can not only to level the voltage imbalance of stresses in SBs, but also provide a complete discharge, rather than operate on schedule «of worse» LIB.
Information about SB condition for ease of use can be transmitted to an integrated CS of hybrid DEPC using a standard digital channel, displayed on the screen or displayed via LEDs using intuitive «traffic light» color symbols.

High-voltage high-capacity SBs are built in a modular approach based on the requirements to ensure electrical safety in the installation and repair as well as the possibility of their transportation and installation with minimum use of handling mechanisms (HM). They are used CSs that also built in a modular approach with 2-3 levels of control.

Safety requirements come to the fore when building powerful ESSs for hybrid DEPCs during their installing, operating, maintenance and repair. An important requirement for reserve SBs is long-term preservation of specifications in the standby mode of connection to the load and ensuring a guaranteed discharging transition mode on a signal, the timing of which is uncertain. Standby time of the battery can vary from a few months to ten years or more. High-capacity SBs can be built in series-parallel or parallel-series circuits [53].

The specified lifetime and uninterruption of LSB operation are achieved: through the use of components and materials with appropriate terms of service; by structural redundancy in SB; through the use of chargers and continuous monitoring of their condition (Fig. 2), which allows for necessary maintenance or repair work on individual LIBs subsystems without removing all batteries from standby mode as soon as possible.

The algorithm of the SB operation provides periodically transition of the storage sections in the test mode in which they are connected to one of the regular loads. Discharge with a nominal current for 0,5 hours is conducted during the tests. According to a voltage magnitude in each LIBs at the end of discharge it is concluded about reduction of their nominal capacity and the possibility of further operation as individual LIBs and chargers as a whole. The test results and available information on the charger standby mode help to make decision about repair work on faulty sections. Defective chargers disconnected from the output ESS buses. All serviceable chargers after the end of test discharge are connected to charger of 4,2 V on any LIBs. A further charge to align the voltage on individual LIBs is performed using internal charging device from ESS.

For parallel LIBs connection in the power circuit of each must be provided protection against overcurrent (e. g. fusible insert) protecting charger from short circuit within individual LIBs and local CS must provide control of their condition.

5.2. Determination of operating modes of hybrid DEPCs with AES in conditions of non-determined loads. Operating modes as DEPCs and SEEs are varying (Table 1). Examples of typical DEPCs operating loads are: dynamic positioning, passage narrow or shallow water at low speed, mooring operation with the loads on the power plant, which differ sharply from each other, working mode, towing and more.

Ship movement in conditions of significant loads is ensured by BEM that working and for SEE charge that can provide energy supply for less intensive load modes: electric propulsion at low speeds, electric lighting, energy supply of electronics and other low-voltage consumers. 
Table 1

Operating loads of DEPC and ESS in general

\begin{tabular}{|l|l|}
\hline \multicolumn{1}{|c|}{ CEE } & \multicolumn{1}{|c|}{ Component of hybrid DEPC } \\
\hline $\begin{array}{l}\text { Disabling/enabling of various switches } \\
\text { while checking or entry into service }\end{array}$ & Activation (excitation of the ship) \\
\hline $\begin{array}{l}\text { Disabling checking, monitoring and } \\
\text { activation (start) }\end{array}$ & $\begin{array}{l}\text { Full DEPC control in the mode of } \\
\text { electric propulsion ship }\end{array}$ \\
\hline $\begin{array}{l}\text { Disabling, monitoring and setting } \\
\text { equalizer devices }\end{array}$ & $\begin{array}{l}\text { Hybrid control } \\
\text { Disabling of the systems for service }\end{array}$ \\
\hline Battery standby & $\begin{array}{l}\text { Mooring — discharge } \\
\text { Mooring — charge }\end{array}$ \\
\hline Battery charge & Standby mode \\
\hline battery discharge & Interoperating ship mooring \\
\hline
\end{tabular}

Reviewing the structures of all-electric and DEPC, the basic principle that is in research of operating modes remain a principle of fuel economy and uninterruptible power supply. All-electric propulsion complexes with SEE are very simple: BEM is driven by SEE, which can be recharged from the land-based network (ship mooring) or from ship AES (PVGS or wind turbines). Hybrid DEPCs may have a different structure.

In the serial hybrid DEPC screw drive is provided or by heat engine in its most efficiency modes, or when it stops for any reason, screw drive is provided by BEM from ESS. BEM in serial hybrid DEPC is operated directly on the screw, getting electricity or from SEEs, or from MSEs, which allows for movement of the ship, even if SBs are discharged.

Addition or power take-off from the propeller shaft are used in the parallel DEPC, providing a heat engine operation with the most efficiency, and when it stops, the screw drive may be from SEE. Propeller drive can be provided as from the heat engine and from BEM, which operates as a «motor/generator» and could either propeller screw, receiving power from SEE or used for SBs charging.

It is used the third type of system - a combination of serial and parallel systems.

Usually, at low loads, heat engine stopped and ship is provided with electric power from SEE, including to the propeller drive. SEEs may be charged from land-based sources, AES or heat engine, rotating propeller when the ship is moving.

DEPC with SEE, which is in continuous operating mode, must meet both cost considerations and environmental standards. Movement of the optimal speed is not always provided, and charging is performed in the final points during the stop. The probability of increasing economic efficiency increases with the installation of additional renewable energy sources, which combined with the existing (proposed) system.

5.3. Simulation of energy processes in hybrid DEPCs with AES in different operating modes for their parameterization and determination of boundary conditions for trouble-free operation. In this section, firstly, we will focus on determination of sizes for SEE, fuel and renewable energy elements and power converters. Then, based on the requirements to $\mathrm{DEPC}$, the purpose of passive components of the converter is given, and, finally, the design process of electronic all-regime controllers is proposed.
The flow of power from DEPC power supply system, assuming n number of MSE, is characterized by the most efficiency of individual elements, namely: diesel $-\eta_{\text {eng }}$, generator $-\eta_{\text {gen }}$ and SB $-\eta_{\text {batt }} . \eta_{d c}-$ average efficiency of power converters, $P_{\text {eng }, 1} \ldots P_{\text {eng }, n}$ and $P_{\text {gen }, 1} \ldots P_{\text {gen }, n}-$ power from each engine and generator, respectively. If SBs discharged, the power of SB $P_{\text {batt }}<0$, if charged $P_{\text {batt }} \geq 0$, measured in watts.

The total load consists of consumers of propulsion, auxiliary elements and their needs, and marked Pload, and should be provided by the energy from MSE and SBs. Considering the efficiency of the relevant components, we get the following equation:

$$
P_{\text {load }}=\sum_{i=1}^{n}\left(P_{\text {gen }, i} \times \eta_{d c}\right)+\left(P_{\text {batt }} \times \eta_{d c} \times \eta_{\text {batt }}\right) .
$$

Basic principles of simulation of the processes in SPU CPC under the influence of non-determined perturbation with several MSEs that working on complex load are considered in [54-56].

Power supply is provided by the main MSEs and hybrid DEPC supports BEM and ESS in good condition to prepare for the unlikely emergency.

According to known principles of construction of dynamic models [54], decomposition [55] of investigated object - CPU CPC, in fact, is separation into interacting parts. Let's present autonomous CPU CPC as a combination of two subsystems: «autonomous MSEs and ESSs energy sources (ES)» and «consumers». With this, apparent partition, the input influence on consumers is generated voltage $U$, and output - load current $I$. Accordingly, for ES, input is load current $I$, and output - voltage $U$. Input and output effects of selected subsystems can be interpreted in different ways. For example, in the study of power supply mode from ESS, parameters $U$ and $I-$ average values of voltage and current are calculated taking into account the allowable pulsation factor $k_{\text {puls max }}$. In the study of power supply mode from AC MSE, U and $I$ - vectors of existing values of voltage and current, and the current vector $I$ is characterized by the module $I$ and argument $\varphi$, and waveform of voltage and current can be easily counted by total harmonic distortion (THD) when working under a load [56].

SPU CPC load is determined by the properties and parameters of individual consumers, especially for operation of energy sources at the consumer of commensurate capacity and also patterns of random processes of formation of group loads, which are the functions of a large number of random factors and their various combinations. Loads may take any values from limited known in advance ranges, and represented by any implementation of the class of functions specified by DEPC property. Therefore, when building a dynamic functional model for SPU CPC it is advisable to describe consumer subsystem by the range of admissible values and loads and by the classes of relevant functions $I(t)$.

In order to present a consumer subsystem in SPU DEPC research, it is necessary to describe its equivalent module - dynamic functional analogue (DFA), through which it can reproduce the main operating modes of SPU $\mathrm{CPC}$ that are adequate to operating and emergency modes.

Obviously, that considered dynamic model is adequate for functioning of autonomous SPU DEPC in the time 
interval $t \leq t_{0} \leq T$, there are such irregularities, where the index «m» are coordinates of dynamic model:

$$
\left.\begin{array}{l}
\left|I(t)-I^{m}(t)\right| \leq \varepsilon_{I} ; \\
\left|U(t)-U^{m}(t)\right| \leq \varepsilon_{U} ; \\
\left|\varphi(t)-\varphi^{m}(t)\right| \leq \varepsilon_{\varphi} ; \\
k_{\text {puls }} \leq k_{\text {puls_max }} \text { or } k_{\text {puls }} \leq k_{T H D} .
\end{array}\right\}
$$

To inequalities $\left|I(t)-I^{m}(t)\right| \leq \varepsilon_{I}$ and $\left|\varphi(t)-\varphi^{m}(t)\right| \leq \varepsilon_{\varphi}$ performing in the specified time range $t \leq t_{0} \leq T$, functional analogue must be a device that operated in directions $I^{m}(t)$ and $\varphi^{m}(t)$. And by providing a fairly small $\varepsilon U$, we can assume that the simulation runs under the same loads of investigated energy sources (MSE and ESS), which in actual operating conditions and therefore, ensuring conditions $\varepsilon_{U} \approx 0, U(t)=U^{m}(t)$ is correct. Harmonic distortion and pulsation factors should be provided with appropriate choice of structural parameters of SPU DEPC model.

When ESS charge is started to its optimal capacity, CS of DEPC connects ESS to AES. At this time, the power of its own consumer subsystem needs should instantly connect to the DC-link, taking into account its dynamic performance, and AESs capacity increases slowly.

When ESS is discharged below the required voltage on the DC-link bus, it is connected to MSE through an appropriate converter to restore voltage to the required level.

Converters control using PWM is a means of pulsation smoothing because it is a component of DC-link, half voltage level is determined in which, for example, as follows [57, 58]:

$$
U_{d c_{-} N}=\frac{1}{\bmod i n d_{-} N} \cdot \frac{U^{m} \sqrt{2}}{\sqrt{3}}(\mathrm{~B}),
$$

where modind $N=1,01$ - value of random variable of optimal switching angles for power converter switches as a function of modulation index to eliminate 5 th, 7 th, ... 25th harmonics from the main.

Then control pulse generation, in terms of getting harmonic voltage shape increases the efficiency of power transmission to consumers and out of the main waveform of output voltage and VSE controllers should operate in the power control mode, because in some cases there is its limitation.

Input and output signals of Energy Management System (EMS) of hybrid DEPC, which block diagram is given in Fig. 1, are shown in Fig. 3.

The analysis of simulation method of different operating modes of SPU DEPC in terms of energy consumption allow to reveal the main criteria for comparing the performance of fuel consumption and state of ESS charge (voltage in the DC-link). The total system efficiency and voltage at each source of energy, which could affect the parameters of operating mode, will be evaluated using an approach of $400 \mathrm{~A}$; based on the reverse wavelet transformation of their instantaneous power using SPU DEPC simulation model in MatLab/Simulink.

IConvBattout

Fig. 3. EMS block diagram of hybrid DEPC: State-of-Charge (50C) ESS charge level, \%; IConvPVout - output current of DC/DC (converter) of PVGS; IConvBattout - output current of DC/DC converter with ESS; Iinv - VSI; IPV_max — the maximum PVGS current; VDC1, VDC2 voltage of DC/DC converter and ESS, respectively; IBat_maxD, IBat_maxS the maximum current value of ESS charge and discharge, respectively;

VBatt - ESS voltage; Res ON — resistor back unit (RBU); Load ON - load connection (consumers)

\section{Research results}

Fig. 4-8 shows the characteristics obtained during the simulation of energy processes in hybrid DEPC for $350 \mathrm{~s}$ in MatLab/Simulink environment. Load profile (consumer subsystem) was determined by equations (2) to $\cos \varphi=0,8$.

At the beginning of the simulation $(t=0 \mathrm{~s})$, the load power is provided by basic MSEs and PVGSs of hybrid DEPC enable for ESS charging and prepare for an emergency.

At $t=40 \mathrm{~s}$, there is a blackout of the ship. EDCS (PMS) switches power supply of the consumer to alternative sources. At that time, the extra power load instantly provided from the DC-Link, which «carried» dumping of energy from the main users, working in generator mode, because PVGS capacity increases slowly.

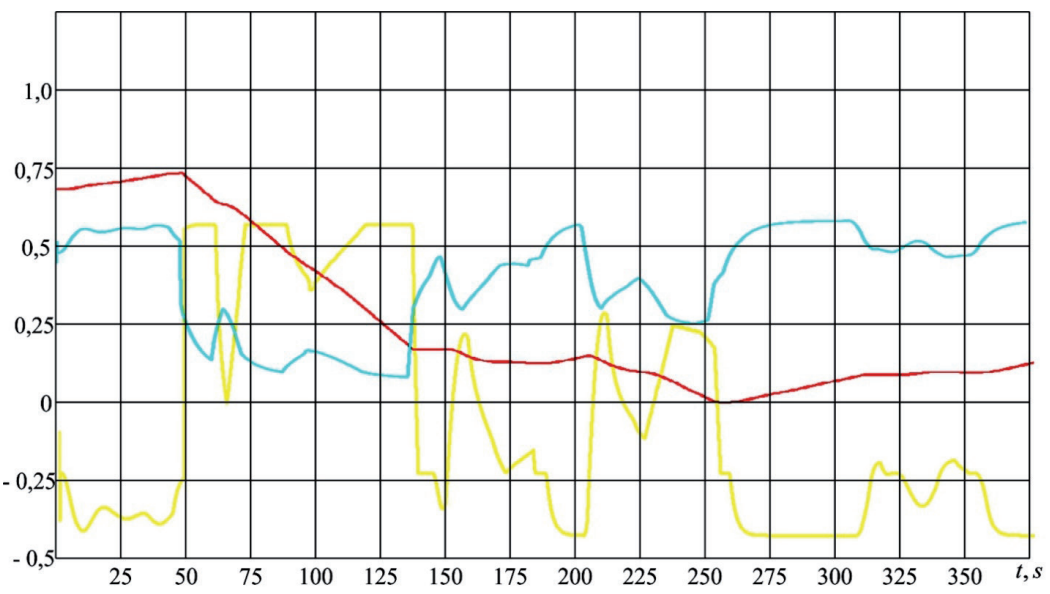

Fig. 4. ESS energy characteristics: —— - maximum current corresponds to the value maximum level of charge corresponds to $100 \%$

At $t=45 \mathrm{~s}$, DC-Link voltage achieves a lower set point $(270 \mathrm{~V})$ and ESS begins recharge the DC-link bus to $450 \mathrm{~V}$, the voltage at which at 47 seconds reaches the desired level and ESS can restrict its capacity slowly to zero. PVGSs provide total power load and continues 
to recharge DC-Link bus. Consumers of emergency mode connect to DC-link bus at 55 second.

At $t=62 \mathrm{~s}$, ESS is enabled to maintain the voltage of DC-Link bus to $450 \mathrm{~V}$ and help PVGS to provide the necessary extra power load.

At 80 seconds, PVGSs reach their maximum capacity, which is limited by the level of $10 \mathrm{~kW}$ because of range of input voltage $\mathrm{DC} / \mathrm{DC}$ and the additional power load is provided by ESS, which maximum power is reached at $t=120 \mathrm{~s}(20 \mathrm{~kW})$ and power supply of the load is provided via the DS-Link bus.

At 130 second, load power is reduced below the maximum PVGS capacity. Due to the low PVGS dynamic performance during transients, additional power supply of consumers with PVGS is switched to DC-Link bus.

At $t=135 \mathrm{~s}$, DC-Link bus voltage up to $450 \mathrm{~V}$, and the charge of ESSs batteries reduces to zero.

Consumers of emergency DEPC mode are enabled again at 140 second and EDCS (PMS) adjustment algorithm with providing the power for necessary consumers is similar to the first case, at $t=55 \mathrm{~s}$.

At $t=165 \mathrm{~s}$, load power reduces below PVGS maximum power and additional power is provided by ESS and DC-Link bus.

At 190 second there is a sudden increase in load due connection of consumers, providing input of DEPC into action and EDCS (PMS) responds quickly, providing extra load power from DC-Link bus, to which PVGS batteries are connected at 195 second for voltage restoration and PVGS support with extra load power PVGS.

The main MSEs of hybrid DEPC start at 250 second and additional ESS energy begin to accumulate in PVGS and DCLink elements.

At $t=260 \mathrm{~s}$, DEPC require an additional capacity due to changes in operating conditions (e. g. - maneuvering of the ship) and PVGS energy is used again to support of the main MSEs.

Ship enters the running mode at 330 second and load power decreases. PVGSs also slowly reduce their capacity to the optimum level and switch to ESS battery charge.

Table 2 shows comparative results of simulation of energy processes for power transmission in hybrid DEPC for two toughest operating modes: emergency operation mode and DP mode under conditions of use of various management strategies for EDCS (PMS).

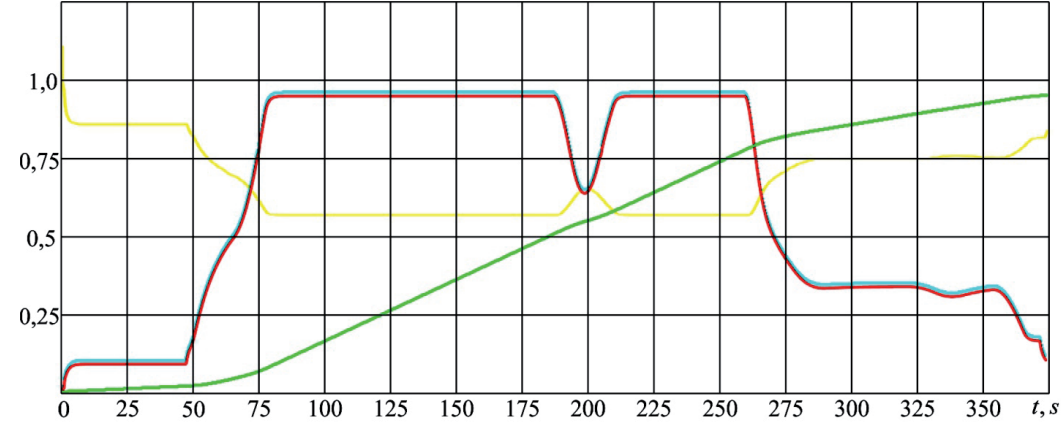

Fig. 5. PVGS energy characteristics: _ _ - maximum voltage corresponds to the value of $170 \mathrm{~V}$; - maximum current corresponds to the value of $250 \mathrm{~A}$; _ maximum level in relation of voltage in PVGS to idle voltage corresponds to the value of 1 ; - PVGS maximum temperature corresponds to the value of $60{ }^{\circ} \mathrm{C}$

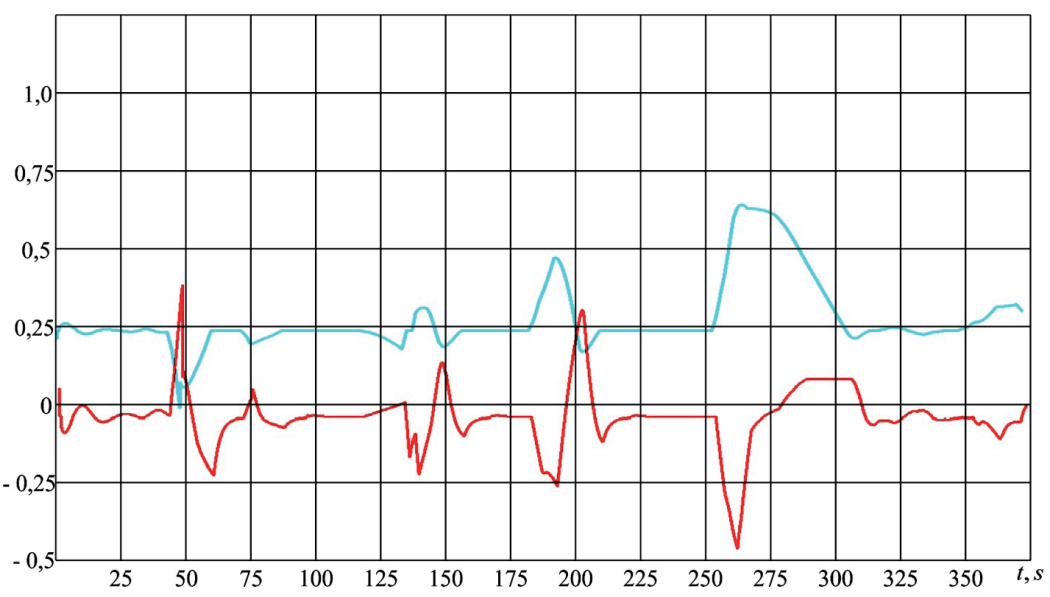

Fig. 6. Dependence of voltage and current in the DC-Link: _ — maximum voltage corresponds to the value of $450 \mathrm{~V}$; - maximum current corresponds to the value of $1000 \mathrm{~A}$

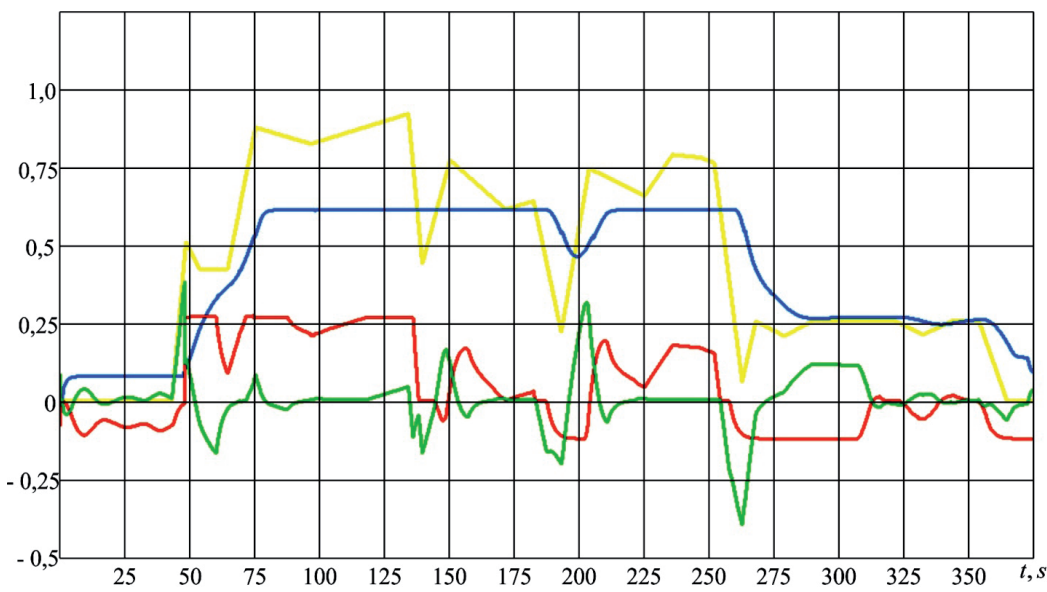

Fig. 7. Characteristics of capacities in different DEPC parts: — - maximum load power corresponds to the value of $1000 \mathrm{~kW}$ _ — maximum capacity in ESS corresponds to the value of $10 \mathrm{~kW}$; - maximum capacity in ESS corresponds to the value of $20 \mathrm{~kW}$; - maximum capacity in DC-Link corresponds to the value of $300 \mathrm{~kW}$

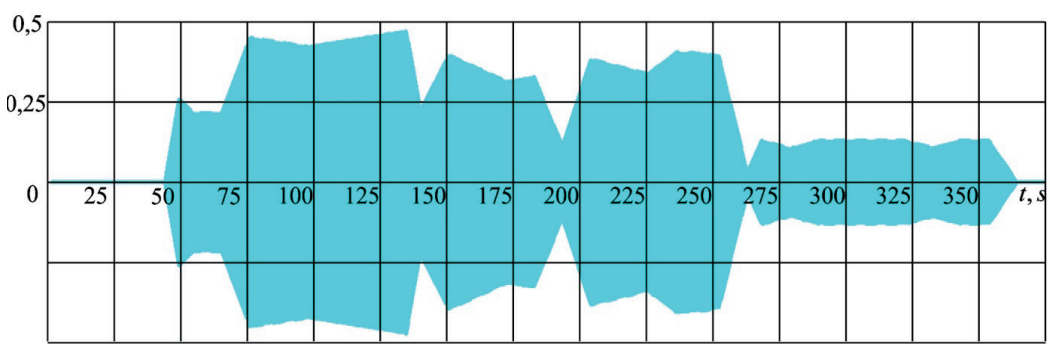

Fig. 8. Dependence of load current: the maximum current corresponds to the value of $3000 \mathrm{~A}$ 
Comparative results of simulation of energy processes for power transmission in hybrid DEPC

\begin{tabular}{|c|c|c|c|c|c|c|c|c|c|c|c|c|c|c|c|c|}
\hline \multirow{3}{*}{$\begin{array}{c}\text { Name of } \\
\text { element }\end{array}$} & \multicolumn{6}{|c|}{ Output data } & \multicolumn{5}{|c|}{$\mathrm{DP}$} & \multicolumn{5}{|c|}{ Emergency operation } \\
\hline & \multirow{2}{*}{$\begin{array}{c}\text { Quan- } \\
\text { tity }\end{array}$} & \multirow{2}{*}{$\begin{array}{c}\text { Installed } \\
\text { capacity, } \\
\text { kW }\end{array}$} & \multirow{2}{*}{$\begin{array}{l}\text { Effi- } \\
\text { ciency }\end{array}$} & \multirow{2}{*}{$\begin{array}{l}\text { Power } \\
\text { factor }\end{array}$} & \multicolumn{2}{|c|}{$\begin{array}{c}\text { Power } \\
\text { consumption, } \mathrm{kW}\end{array}$} & \multirow{2}{*}{$\begin{array}{c}\text { Diversity } \\
\text { factor }\end{array}$} & \multirow{2}{*}{$\begin{array}{c}\text { Coeffi- } \\
\text { cient of } \\
\text { loading }\end{array}$} & \multirow{2}{*}{$\begin{array}{l}\text { Power } \\
\text { factor }\end{array}$} & \multicolumn{2}{|c|}{ Power consumption } & \multirow{2}{*}{$\begin{array}{c}\text { Diversity } \\
\text { factor }\end{array}$} & \multirow{2}{*}{$\begin{array}{c}\text { Coef- } \\
\text { ficient } \\
\text { of loa- } \\
\text { ding }\end{array}$} & \multirow{2}{*}{$\begin{array}{c}\text { Power } \\
\text { factor }\end{array}$} & \multicolumn{2}{|c|}{$\begin{array}{c}\text { Power } \\
\text { consumption }\end{array}$} \\
\hline & & & & & Single & Total & & & & $\begin{array}{c}\text { Active } \\
\text { power, kW }\end{array}$ & $\begin{array}{c}\text { Reactive } \\
\text { power, } \\
\text { kBAr }\end{array}$ & & & & $\begin{array}{c}\text { Active } \\
\text { power, } \\
\text { kW }\end{array}$ & $\begin{array}{c}\text { Reactive } \\
\text { power, } \\
\text { kBAr }\end{array}$ \\
\hline \multicolumn{17}{|c|}{ Hybrid Propulsion Complex } \\
\hline PVG5 & 10 & 11,5 & 0,94 & 1,00 & 12,2 & 122,3 & 1,0 & 1,0 & 1,00 & 122,34 & 0,00 & 1,0 & 0,8 & 1,00 & 97,87 & 0,00 \\
\hline ESS & 2 & 100,0 & 0,93 & 1,00 & 107,5 & 215,1 & 1,0 & 1,0 & 1,00 & 215,05 & 0,00 & 1,0 & 0,9 & 1,00 & 193,55 & 0,00 \\
\hline $\begin{array}{l}\text { DC/DC } \\
\text { converters }\end{array}$ & 2 & 200,0 & 0,88 & 1,00 & 227,3 & 454,5 & 1,0 & 1,0 & 1,00 & 454,55 & 0,00 & 0,5 & 0,8 & 1,00 & 181,82 & 0,00 \\
\hline VSI & 2 & 400,0 & 0,80 & 0,69 & 500,0 & 1000,0 & 1,0 & 1,0 & 0,69 & 1000,00 & 723,81 & 0,5 & 0,9 & 0,69 & 450,00 & 325,71 \\
\hline DC-Link & 1 & 300,0 & 0,80 & 0,69 & 375,0 & 375,0 & 1,0 & 1,0 & 0,69 & 375,00 & 271,43 & 1,0 & 0,8 & 0,69 & 281,25 & 203,57 \\
\hline HVSB & 2 & 611,5 & 0,88 & 0,43 & 694,9 & 1389,8 & 1,0 & 1,0 & 0,43 & 1389,77 & 1254,73 & 0,5 & 0,8 & 0,43 & 583,70 & 526,99 \\
\hline LVSB & 2 & 1311,5 & 0,89 & 0,44 & 1473,6 & 2947,2 & 1,0 & 1,0 & 0,44 & 2947,19 & 2646,57 & 0,5 & 1,0 & 0,44 & 1414,65 & 1270,35 \\
\hline Load & 2 & 1923,0 & 0,95 & 0,80 & 2024,2 & 4048,4 & 1,0 & 1,0 & 0,80 & 4048,42 & 2429,05 & 0,5 & 1,0 & 0,80 & 2024,21 & 1214,53 \\
\hline \multicolumn{7}{|c|}{ State machine control strategy } & \multicolumn{3}{|c|}{0,70} & 10552,3 & 7325,6 & \multicolumn{3}{|c|}{0,70} & 4022,6 & 3011,9 \\
\hline \multicolumn{7}{|c|}{ Classical PI control strategy with SOC's regulation } & \multicolumn{3}{|c|}{0,75} & 21104,6 & 14651,2 & \multicolumn{3}{|c|}{0,75} & 4847,9 & 3337,6 \\
\hline \multicolumn{7}{|c|}{$\begin{array}{l}\text { Frequency decoupling and state machine control strategy } \\
\text { with SOC's regulation }\end{array}$} & \multicolumn{3}{|c|}{0,80} & 16883,7 & 11720,9 & \multicolumn{3}{|c|}{0,85} & 4120,7 & 2836,9 \\
\hline \multicolumn{7}{|c|}{ Equivalent consumption minimization strategy } & \multicolumn{3}{|c|}{0,85} & 17727,9 & 12307,0 & \multicolumn{3}{|c|}{0,90} & 4326,8 & 2978,8 \\
\hline \multicolumn{7}{|c|}{$\begin{array}{l}\text { External energy maximization strategy with SOC's } \\
\text { regulation }\end{array}$} & \multicolumn{3}{|c|}{0,90} & 18614,3 & 12922,3 & & 0,95 & & 4543,1 & 3127,7 \\
\hline & & & & & & & & oC's reg. & & yes & no & & J's reg & & yes & no \\
\hline
\end{tabular}

\section{SWOT-analysis of research results}

The above results of simulation of energy processes in hybrid DEPC make it possible to solve the problem of structuring of the last through the introduction of new types of power semiconductor technology and highly automated management technologies. The combination of these components allows to build flexible multifunction electricity generating system integrated into a hybrid DEPC as an integral part of it.

But given the fact that the regulation of the battery charge level is incidentally impact on reducing consumption of reactive power (Table 2) and power supply of inverters by unregulated rectified voltage creates a problem of energy recovery in the system of ship electricity consumers, we can conclude that the electromechanical compensation of reactive power of consumers mainly done using MSE that transferred by its PID controller in compensator mode.

Further studies will be conducted to verify the obtained results on a physical model of multifunctional propulsive complex, which was created as a part of research work «Concepts, technologies and ways of improvement of ship power units (SPU) of combined propulsive complexes» (CPC) of the National University «Odessa Marine Academy» (state registration number 0114U000340) [59-61].

In particular, it is necessary to point out that the composition of DEPC includes auxiliary diesel or turbogenerators as the main source of heat and mechanical energy, the part of which is converted into electricity, and at other special conditions of utilization, in turn, must take into account the heat loss in their workflow. Particular attention in the development of block diagrams of hybrid DEPC should be paid to automate control of the entire energy complex, including subsystems of collection and processing of measurement data, coordinated control of individual power converters, generators and their excitation system, power semiconductor and switching devices, various mechanisms and their controllers interrelated to different hierarchical levels. In addition, the electricity generating system must satisfy often contradictory requirements arising from the appointment of the ship, divergent performance of the same equipment of different manufacturers, and features of its use, as well as being highly reliable with the necessary degree of redundancy and maintainability.

\section{Conclusions}

1. It is established that improving the operating modes of hybrid diesel-electric propulsive complexes is possible through the use of modern energy storage systems using solar generating elements and optimal battery capacity.

2. The dynamic performances of power transmission parameters in different parts of hybrid diesel-electric propulsive complex are obtained. They can work out the principles of the electric power distribution control systems management for different operating modes in terms of non-determined load. For example, analyzing the data in the Table 2, it can be concluded that the application of the classical PI control with adjustable degree of ESS battery charge decreases power consumption by consumers connected to the DC-link within $5 \div 7 \%$ depending on the operating mode, and reactive power compensation is 
achieved within $2 \div 3 \%$. If to apply a control using the criterion of minimum power consumption, in this case there is an increase of pulsation factor of the output voltage within $1 \div 1,5 \%$, which can't be offset without the support of ESS battery charge level at $85 \div 95 \%$.

3. Energy processes in hybrid diesel-electric propulsive complex with alternative sources of electricity in the different operating modes of the ship are modeled. On the one hand, it provides a reasonable range of currentvoltage characteristics of photovoltaic panels and the batteries of energy storage systems in terms of optimum charge/discharge cycles, on the other hand, allows to perform parameterization of the basic energy sources and to determine the boundary conditions of trouble-free operation. For example, analyzing dependences and data in Table 2, we can conclude that the control of frequency and MSE conditions with adjustable degree of ESS battery charge with all other equal conditions to operating mode can reduce the number or power of ESS modules by $7 \div 10 \%$ and management for criteria to obtain a maximum of alternative energy and control of the charge degree of ESS battery allows to use batteries of smaller capacity within $6 \div 8 \%$.

\section{References}

1. Livanosa, G. A. Techno-economic investigation of alternative propulsion plants for Ferries and RoRo ships [Text] G. A. Livanosa, G. Theotokatos, D.-N. Pagonis // Energy Conversion and Management. - 2014. - Vol. 79. - P. 640-651. doi:10.1016/j.enconman.2013.12.050

2. Abdin, Z. Solar hydrogen hybrid energy systems for offgrid electricity supply: A critical review [Text] / Z. Abdin, C. J. Webb, E. M. Gray // Renewable and Sustainable Energy Reviews. - 2015. - Vol. 52. - P. 1791-1808. doi:10.1016/ j.rser.2015.08.011

3. Matthé, U. The Voltec System - Energy Storage and Electric Propulsion [Text] / R. Matthé, U. Eberle // Lithium-Ion Batteries. - 2014. - P. 151-176. doi:10.1016/b978-0-44459513-3.00008-x

4. Bajec, P. Optimal control of brushless PM motor in parallel hybrid propulsion system [Text] / P. Bajec, B. Pevec, D. Miljavec // Mechatronics. - 2010. - Vol. 20, № 4. - P. 464-473. doi:10.1016/j.mechatronics.2010.04.004

5. Mander, S. Slow steaming and a new dawn for wind propulsion: A multi-level analysis of two low carbon shipping transitions [Electronic resource] / S. Mander // Marine Policy. 2016. - Available at: \www/URL: https://doi.org/10.1016/ j.marpol.2016.03.018

6. Johnson, H. Increased energy efficiency in short sea shipping through decreased time in port [Text] / H. Johnson, L. Styhre // Transportation Research Part A: Policy and Practice. - 2015. Vol. 71. - P. 167-178. doi:10.1016/j.tra.2014.11.008

7. Johnson, H. Barriers to improving energy efficiency in short sea shipping: an action research case study [Text] / H. Johnson, M. Johansson, K. Andersson // Journal of Cleaner Production. - 2014. - Vol. 66. - P. 317-327. doi:10.1016/ j.jclepro.2013.10.046

8. Wilflinger, J. Simulation and control design of hybrid propulsions in boats [Text] / J. Wilflinger, P. Ortner, L. del Re, M. Aschaber // IFAC Proceedings Volumes. - 2010. - Vol. 43 № 20. - P. 40-45. doi:10.3182/20100915-3-de-3008.00001

9. Choi, C. H. Development and demonstration of PEM fuel-cellbattery hybrid system for propulsion of tourist boat [Text] / C. H. Choi, S. Yu, I.-S. Han, B.-K. Kho, D.-G. Kang et al. // International Journal of Hydrogen Energy. - 2016. - Vol. 41, № 5. - P. 3591-3599. doi:10.1016/j.ijhydene.2015.12.186

10. de-Troya, J. J. Analysing the possibilities of using fuel cells in ships [Text] / J. J. de-Troya, C. Alvarez, C. FernandezGarrido, L. Carral // International Journal of Hydrogen Energy. - 2016. - Vol. 41, № 4. - P. 2853-2866. doi:10.1016/ j.ijhydene.2015.11.145
11. Zahedi, B. Optimized efficiency of all-electric ships by dc hybrid power systems [Text] / B. Zahedi, L. E. Norum, K. B. Ludvigsen // Journal of Power Sources. - 2014. - Vol. 255. P. 341-354. doi:10.1016/j.jpowsour.2014.01.031

12. Yan, R. The combined effects of high penetration of wind and PV on power system frequency response [Text] / R. Yan, T. K. Saha, N. Modi, N.-A. Masood, M. Mosadeghy // Applied Energy. - 2015. - Vol. 145. - P. 320-330. doi:10.1016/ j.apenergy.2015.02.044

13. Balcombe, P. Environmental impacts of microgeneration: integrating solar PV, Stirling engine CHP and battery storage [Text] / P. Balcombe, D. Rigby, A. Azapagic // Applied Energy. - 2015. - Vol. 139. - P. 245-259. doi:10.1016/ j.apenergy.2014.11.034

14. Cho, J. Energy storage systems in energy and ancillary markets: a backwards induction approach [Text] / J. Cho, A. N. Kleit // Applied Energy. - 2015. - Vol. 147. - P. 176-183. doi:10.1016/ j.apenergy.2015.01.114

15. Zhao, H. Review of energy storage system for wind power integration support [Text] / H. Zhao, Q. Wu, S. Hu, H. Xu, C. N. Rasmussen // Applied Energy. - 2014. - Vol. 137. P. 545-553. doi:10.1016/j.apenergy.2014.04.103

16. Allan, G. The economics of distributed energy generation: a literature review [Text] / G. Allan, I. Eromenko, M. Gilmartin, I. Kockar, P. McGregor // Renewable and Sustainable Energy Reviews. - 2015. - Vol. 42. - P. 543-556. doi:10.1016/ j.rser.2014.07.064

17. Arifujjaman, M. A comprehensive power loss, efficiency, reliability and cost calculation of a $1 \mathrm{MW} / 500 \mathrm{kWh}$ battery based energy storage system for frequency regulation application [Text] / M. Arifujjaman // Renewable Energy. - 2015. Vol. 74. - P. 158-169. doi:10.1016/j.renene.2014.07.046

18. Zhao, P. Capacity allocation of a hybrid energy storage system for power system peak shaving at high wind power penetration level [Text] / P. Zhao, J. Wang, Y. Dai // Renewable Energy. - 2015. - Vol. 75. - P. 541-549. doi:10.1016/j.renene.2014.10.040

19. Zakeri, B. Electrical energy storage systems: a comparative life cycle cost analysis [Text] / B. Zakeri, S. Syri // Renewable and Sustainable Energy Reviews. - 2015. - Vol. 42. P. 569-596. doi:10.1016/j.rser.2014.10.011

20. Chen, C. Optimal allocation and economic analysis of energy storage system in microgrids [Text] / C. Chen, S. Duan, T. Cai, B. Liu, G. Hu // IEEE Transactions on Power Electronics. 2011. - Vol. 26, № 10. - P. 2762-2773. doi:10.1109/ TPEL.2011.2116808

21. Bigdeli, N. Optimal management of hybrid PV/fuel cell/battery power system: a comparison of optimal hybrid approaches [Text] / N. Bigdeli // Renewable and Sustainable Energy Reviews. - 2015. - Vol. 42. - P. 377-393. doi:10.1016/ j.rser.2014.10.032

22. Kurzweil, P. Post-lithium-ion battery chemistries for hybrid electric vehicles and battery electric vehicles [Text] / P. Kurzweil // Advances in Battery Technologies for Electric Vehicles. 2015. - P. 127-172. doi:10.1016/B978-1-78242-377-5.00007-8

23. Dedes, E. K. Assessing the potential of hybrid energy technology to reduce exhaust emissions from global shipping [Text] / E. K. Dedes, D. A. Hudson, S. R. Turnock // Energy Policy. 2012. - Vol. 40. - P. 204-218. doi:10.1016/j.enpol.2011.09.046

24. Wang, L. Analysis of a novel autonomous marine hybrid power generation/energy storage system with a high-voltage direct current link [Text] / L. Wang, D. J. Lee, W. J. Lee, Z. Chen // Journal of Power Sources. - 2008. - Vol. 185. - P. 1284-1292. doi:10.1016/j.jpowsour.2008.08.037

25. Bal Besikci, E. An artificial neural network based decision support system for energy efficient ship operations [Text] / E. Bal Besikci, O. Arslan, O. Turan, A. L. Olcer // Computers \& Operations Research. - 2016. - Vol. 66. - P. 393-401. doi:10.1016/j.cor.2015.04.004

26. Maleki, A. Artificial bee swarm optimization for optimum sizing of a stand-alone PV/WT/FC hybrid system considering LPSP concept [Text] / A. Maleki, A. Askarzadeh // Solar Energy. - 2014. - Vol. 107. - P. 227-235. doi:10.1016/ j.solener.2014.05.016 
27. Maleki, A. Optimal sizing of a PV/wind/diesel system with battery storage for electrification to an off-grid remote region: a case study of Rafsanjan, Iran [Text] / A. Maleki, A. Askarzadeh // Sustainable Energy Technologies and Assessments. 2014. - Vol. 7. - P. 147-153. doi:10.1016/j.seta.2014.04.005

28. Nelson, D. B. Unit sizing and cost analysis of stand-alone hybrid wind/PV/fuel cell power generation systems [Text] D. B. Nelson, M. N. Nehrir, C. Wang // Renewable Energy. - 2006. - Vol. 31, № 10. - P. 1641-1656. doi:10.1016/ j.renene.2005.08.031

29. Budashko, V. V. Udoskonalennia systemy upravlinnia pidruliuiuchym prystroiem kombinovanoho propulsyvnoho kompleksu [Text] / V. V. Budashko, O. A. Onyshchenko // Bulletin of NTU «KhPI». Thematic edition «Electric Machines and Electromechanical Energy Conversion». - 2014. - № 38 (1081). P. $45-51$.

30. Rezzouk, H. Feasibility study and sensitivity analysis of a stand-alone photovoltaic-diesel-battery hybrid energy system in the north of Algeria [Text] / H. Rezzouk, A. Mellit // Renewable and Sustainable Energy Reviews. - 2015. - Vol. 43. P. 1134-1150. doi:10.1016/j.rser.2014.11.103

31. Ramli, M. A. M. Economic analysis of PV/diesel hybrid system with flywheel energy storage [Text] / M. A. M. Ramli, A. Hiendro, S. Twaha // Renewable Energy. - 2015. - Vol. 78. P. 398-405. doi:10.1016/j.renene.2015.01.026

32. Maheri, A. Multi-objective design optimization of standalone hybrid wind-PV-diesel systems under uncertainties [Text] A. Mahery // Renewable Energy. - 2014. - Vol. 66. P. 650-661. doi:10.1016/j.renene.2014.01.009

33. Zhao, B. Optimal sizing, operating strategy and operational experience of a stand-alone microgrid on Dongfushan Island [Text] / B. Zhao, X. Zhang, P. Li, K. Wang, M. Xue, C. Wang // Applied Energy. - 2014. - Vol. 113. - P. 1656-1666. doi:10.1016/ j.apenergy.2013.09.015

34. Glykas, A. Application and cost-benefit analysis of solar hybrid power installation on merchant marine vessels [Text] / A. Glykas, G. Papaioannou, S. Perissakis // Ocean Engineering. 2010. - Vol. 37, № 7. - P. 592-602. doi:10.1016/j.oceaneng.2010.01.019

35. Lee, K. J. Hybrid photovoltaic/diesel green ship operating in standalone and grid-connected mode in South Korea - Experimental investigation [Text] / K. J. Lee, D. S. Shin, J. P. Lee, D. W. Yoo, H. K. Choi, H. J. Kim // 2012 IEEE Vehicle Power and Propulsion Conference (VPPC). - 2012. - Vol. 49. P. 580-583. doi:10.1109/VPPC.2012.6422691

36. Adamo, F. Estimation of ship emissions in the port of Taranto [Text] / F. Adamo, G. Andria, G. Cavone, C. De Capua, A. M. L. Lanzolla, R. Morello, M. Spadavecchia // Measurement. - 2014. - Vol. 47. - P. 982-988. doi:10.1016/j.measurement.2013.09.012

37. Jeyaprabha, S. B. Optimal sizing of photovoltaic/battery/diesel based hybrid system and optimal tilting of solar array using the artificial intelligence for remote houses in India [Text] / S. B. Jeyaprabha, A. L. Selvakumar // Energy and Buildings. 2015. - Vol. 96. - P. 40-52. doi:10.1016/j.enbuild.2015.03.012

38. Rezaie, B. Renewable energy options for buildings: case studies [Text] / B. Rezaie, E. Esmailzadeh, I. Dincer // Energy and Buildings. - 2011. - Vol. 43, № 1. - P. 56-65. doi:10.1016/ j.enbuild.2010.08.013

39. Diaf, S. Design and technoeconomical optimization for hybrid $\mathrm{PV} /$ wind system under various meteorological conditions [Text] / S. Diaf, G. Notton, M. Belhamel, M. Haddadi, A. Louche // Applied Energy. - 2008. - Vol. 85, № 10. P. 968-987. doi:10.1016/j.apenergy.2008.02.012

40. Sharafi, M. Multi-objective optimal design of hybrid renewable energy systems using PSO-simulation based approach [Text] M. Sharafi, T. Y. ELMekkawy // Renewable Energy. - 2014. Vol. 68. - P. 67-79. doi:10.1016/j.renene.2014.01.011

41. Lujano-Rojas, J. M. Probabilistic modelling and analysis of stand-alone hybrid power systems [Text] / J. M. Lujano-Rojas, R. Dufo-Lopez, J. L. Bernal-Agustin // Energy. - 2013. Vol. 63. - P. 19-27. doi:10.1016/j.energy.2013.10.003

42. Yoshida, S. Estimation of global tilted irradiance and output energy using meteorological data and performance of photovoltaic modules [Text] / S. Yoshida, S. Ueno, N. Kataoka, H. Takakura, T. Minemoto // Solar Energy. - 2013. - Vol. 93. P. 90-99. doi:10.1016/j.solener.2013.04.001
43. Ovrum, E. Modelling lithium-ion battery hybrid ship crane operation [Text] / E. Ovrum, T. F. Bergh // Applied Energy. - 2015. - Vol. 152. - P. 162-172. doi:10.1016/j.apenergy.2015.01.066

44. Diab, F. Novel comparison study between the hybrid renewable energy systems on land and on ship [Text] / F. Diab, H. Lan, S. Ali // Renewable and Sustainable Energy Reviews. - 2016. Vol. 63. - P. 452-463. doi:10.1016/j.rser.2016.05.053

45. Li, C.-Z. Fundamentals of Renewable Energy Processes [Text] C.-Z. Li // Process Safety and Environmental Protection. 2006. - Vol. 84, № 6. - P. 476. doi:10.1205/psep.br.0606

46. Zhao, J. Thermal performance of mini-channel liquid cooled cylinder based battery thermal management for cylindrical lithium-ion power battery [Text] / J. Zhao, Z. Rao, Y. Li // Energy Conversion and Management. - 2015. - Vol. 103. P. 157-165. doi:10.1016/j.enconman.2015.06.056

47. Ordonez, J. Processes and technologies for the recycling and recovery of spent lithium-ion batteries [Text] / J. Ordonez, E. J. Gago, A. Girard // Renewable and Sustainable Energy Reviews. - 2016. - Vol. 60. - P. 195-205. doi:10.1016/ j.rser.2015.12.363

48. Wang, Q. A critical review of thermal management models and solutions of lithium-ion batteries for the development of pure electric vehicles [Text] / Q. Wang, B. Jiang, B. Li, Y. Yan // Renewable and Sustainable Energy Reviews. - 2016. - Vol. 64. P. 106-128. doi:10.1016/j.rser.2016.05.033

49. Zhou, Y. A novel health indicator for on-line lithium-ion batteries remaining useful life prediction [Text] / Y. Zhou, M. Huang, Y. Chen, Y. Tao // Journal of Power Sources. 2016. - Vol. 321. - P. 1-10. doi:10.1016/j.jpowsour.2016.04.119

50. Hassan, S. R. Evaluation of Propulsion System Used in URRG-Autonomous Surface Vessel (ASV) [Text] / S. R. Hassan, M. Zakaria, M. R. Arshad, Z. A. Aziz // Procedia Engineering. - 2012. - Vol. 41. - P. 607-613. doi:10.1016/ j.proeng.2012.07.219

51. Delucchi, M. A. Providing all global energy with wind, water and solar power, Part II: Reliability, system and transmission costs, and policies [Text] / M. A. Delucchi, M. Z. Jacobson // Energy Policy. - 2011. - Vol. 39, № 3. - P. 1170-1190. doi:10.1016/j.enpol.2010.11.045

52. Ketsingsoi, S. An Off-line Battery Charger based on Buckboost Power Factor Correction Converter for Plug-in Electric Vehicles [Text] / S. Ketsingsoi, Y. Kumsuwan // Energy Procedia. - 2014. - Vol. 56. - P. 659-666. doi:10.1016/ j.egypro.2014.07.205

53. Yang, N. Unbalanced discharging and aging due to temperature differences among the cells in a lithium-ion battery pack with parallel combination [Text] / N. Yang, X. Zhang, B. Shang, G. Li // Journal of Power Sources. - 2016. - Vol. 306. P. 733-741. doi:10.1016/j.jpowsour.2015.12.079

54. Budashko, V. V. Mathematical principles of simulation of power plant's control system at drillship [Electronic resource] / V. V. Budashko, O. A. Onishchenko // Bulletin of Kamchatka State Technical University. - 2014. - Vol. 29. P. 6-13. - Available at: \www/URL: http://elibrary.ru/item. asp?id $=22822710$

55. Hlazeva, O. V. Aspects of the mathematical modelling of the elements for Western Systems Coordinating Council of combined propulsion complexes [Electronic resource] / O. V. Hlazeva, V. V. Budashko // Bulletin of NTU «KhPI». Thematic edition «Problems of Electrical Machines and Apparatus Perfection. The Theory and Practice». - 2015. - № 42 (1151). P. 71-75. - Available at: \www/URL: http://pema.khpi.edu.ua/ index.php/2079-3944/article/view/55969

56. Budashko, V. Implementation approaches during simulation of energy processes for a dynamically positioned ship [Electronic resource] / V. Budashko // Electrical Engineering \& Electromechanics. - 2015. - № 6. - P. 14-19. - Available at: \www/ URL: http://eie.khpi.edu.ua/article/view/2074-272X.2015.6.02

57. Motapon, S. N. A Comparative Study of Energy Management Schemes for a Fuel-Cell Hybrid Emergency Power System of More-Electric Aircraft [Text] / S. N. Motapon, L.-A. Dessaint, K. Al-Haddad // IEEE Transactions on Industrial Electronics. - 2014. - Vol. 61, № 3. - P. 1320-1334. doi:10.1109/ TIE.2013.2257152 
58. Budashko, V. Physical model of degradation effect by interaction azimuthal flow with hull of ship [Text] / V. Budashko, V. Nikolskyi, O. Onishchenko, S. Khniunin // Proceeding Book of International Conference on Engine Room Simulators (ICERS12). Istanbul: Istanbul Technical University, Maritime Faculty, 2015. P. 49-53. - ISBN 978-605-01-0782-1.

59. Nikolskyi, V. The monitoring system of the Coanda effect for the tension-leg platform's [Text] / V. Nikolskyi, V. Budashko, S. Khniunin // Proceeding Book of International Conference on Engine Room Simulators (ICERS12). - Istanbul: Istanbul Technical University, Maritime Faculty, 2015. - P. 45-49. ISBN 978-605-01-0782-1

60. Ship monitoring system for the prevention of Coanda effect [Electronic resource]: Patent of Ukraine № 100819 / Budashko V. V., Nikolskyi V. V., Khniunin S. H.; assignee: Odesa National Maritime Academy, Budashko V. V., Nikolskyi V. V. Khniunin S. H. - № u201501854. Filed 02.03.2015. Published 10.08.2015, Bull. № 15. - Available at: \www/URL: http:// base.uipv.org/searchINV/search.php?action=viewdetails\&IdCla $\mathrm{im}=215069 \&$ chapter $=$ biblio

61. Budashko, V. Physical Modeling of Multi-Propulsion Complex [Electronic resource] / V. Budashko, O. Onischenko, E. Yushkov // Zbirnyk naukovykh prats Viiskovoi akademii (m. Odesa), Tekhnichni nauky. - 2014. - № 2. P. 88-92. - Available at: \www/URL: http://zbirnyk.vaodessa. org.ua/images/zbirnyk_2/13.PDF

\section{КОНЦЕПТУАЛИЗАЦИЯ ИССЛЕДОВАНИЙ СУДОВЫХ ГИБРИДНЫХ ЭЛЕКТРОЭНЕРГЕТИЧЕСКИХ КОМПЛЕКСОВ}

На основе анализа способов моделирования различных эксплуатационных режимов судовой энергетической установки (СЭУ) гибридного дизель-электрического пропульсивного комплекса (ДЭПК) с точки зрения потребления энергии, получены динамические характеристики процессов передачи мощностей на разных участках гибридного ДЭПК. Это позволило концептуализировать принципы наладки систем управления распределением электроэнергии для различных эксплуатационных режимов в условиях недетерминированных нагрузок.

Ключевые слова: гибридный пропульсивный комплекс, альтернативный источник энергии, солнечный генерирующий элемент, аккумуляторная батарея, моделирование.

Будашко Віталій Віталійович, кандидат технічних наук доцент, докторант, кафедра технічної експлуатаціі флоту, Національний університет «Одеська морська академія», Україна, e-mail: bvv@te.net.ua.

Глазєва Оксана Володимирівна, кандидат технічних наук, доцент, кафедра суднової електромеханіки і електротехніки, Національний університет «Одеська морська академія», Україна, e-mail: Glazeva@bk.ru.

Самонов Сергій Федорович, кандидат технічних наук, до иент, кафедра суднової електромеханіки і електротехніки, На иіональний університет «Одеська морська академія», Україна, e-mail: samonovsf@gmail.com.

Будашко Виталий Витальевич, кандидат технических на ук, доцент, докторант, кафедра технической эксплуатации флота, Национальный университет «Одесская морская академия», Украина

Глазева Оксана Владимировна, кандидат технических наук, доцент, кафедра судовой электромеханики и электротехники, Национальный университет «Одесская морская академия», Украина.

Самонов Сергей Фёдорович, кандидат технических наук, доцент, кафедра судовой электромеханики и электротехники, Национальный университет «Одесская морская академия», Украина

Budashko Vitaliy, National University «Odessa Maritime Academy», Ukraine,e-mail:bvv@te.net.ua.

Glazeva Oksana, National University «Odessa Maritime Academy», Ukraine,e-mail: Glazeva@bk.ru.

Samonov Sergey, National University «Odessa Maritime Academy», Ukraine, e-mail: samonovsf@gmail.com 